\title{
Positive Acceptance of Morocco against Postitory Retirement Refugees 2011
}

\author{
Hamza Fadil ${ }^{1, *} \&$ Shen $\mathrm{Yi}^{1}$ \\ ${ }^{1}$ Department of Sociology, School of Public Administration, Hohai University, Nanjing, \\ China \\ *Correspondence: Department of Sociology, School of Public Administration, Hohai \\ University, Nanjing, China. E-mail: h-fadil@hotmail.com
}

Received: October 2, 2019 Accepted: November 14, 2019 Published: December 2, 2019

doi:10.5296/jsr.v11i1.15961ＵRL: https://doi.org/10.5296/jsr.v11i1.15961

\begin{abstract}
Morocco is a country in the North African region with a strategic geographical location for migration routes to Europe. Morocco borders Spain directly, causing thousands of migrants, refugees and asylum seekers to pass through Morocco as a transit country to get to Europe as a major destination. Previously, Morocco itself was a large migrant sending country with a total Moroccan diaspora abroad reaching almost $10 \%$ of the total population. The dynamics of Morocco as a sending, transit and now a recipient country for refugees makes Morocco have a policy dynamic that is quite interesting to study. Starting with Law 02-03 which made Morocco the first Arab country to have regulations on refugees, ratification of the 2011 constitution, until the enactment of the National Policy on Immigration and Asylum (NPIA) in 2013 made Morocco continue to get praise from various parties for its quite friendly regulations against these refugees, despite various diplomatic pressures that Morocco has received from other countries such as Spain and Greece. Morocco then offers permanent residency for refugees who fulfill the procedure. In discussing the motives behind Morocco's positive response, Jacobsen's concept of influencing factors influencing Jacobsen's explanations explains 4 variable factors: international relations, national security considerations, the competitiveness of local communities, and bureaucratic decisions.
\end{abstract}

Keywords: refugee policy choices, refugee, migration, Maroko 


\section{Research Background}

Morocco has had a long journey in the dynamics of its relations with migrants and refugees. Morocco became one of the earliest countries to sign and ratify the 1951 Tahin Convention on refugees, while Morocco ratified it on 7 November 1956. As for the 1967 Protocol on refugees, Morocco ratified it on 20 April 1971. Morocco itself has sent many migrants to abroad since the 1960s. Until now the number of Moroccans in other countries continues to increase where in 2015 alone there were approximately 4 million Moroccans becoming migrants in other countries, this then becomes a quite large number when compared with the Moroccan population of only 34 million (Mehdi, 2015). But the trend of Morocco as a sending country for migrants actually has shifted a lot since 2009, where Morocco began to be a transit country for migrants and refugees who want to enter Europe. The arrival of massive migrants and refugees starting in the 1990s has implications for changes in some of Morocco's policy and regulatory points regarding migrants who transit to their countries. However, in the mid-era up to the early $2000 \mathrm{~s}$, Morocco experienced a period in the later period which was called the period of non-migration policy or a period marked by the high number of migrants who transit. However, the Moroccan government does not provide a significant response to this phenomenon because the Moroccan government considers that migrants who transit are not considered to pose any significant threats.

In the early 2000 s to post 2006 , Morocco experienced many changes in the regulation of migrants where this was more influenced by the dynamics of migrant reception in the European Union so that Morocco was required to be willing to adapt or adjust to these regulations. One of them was in 2002-2003 when Spain and Greece then began to implement policies to adjust migrants' acceptance and force Morocco to work in reducing or inhibiting the flow of migrants, both legal and illegal to the mainland of Europe. The influx of refugees to Morocco became more massive when at the end of 2010 the Arab Spring in Tunisia expanded to Turkey and had implications for regional security disturbances. Arab spring itself later became the cause of the emergence of internally displaced people in various countries and forced them to flee to other countries. Morocco, which at that time also experienced political turbulence, although it was not as severe as other countries such as Egypt and Libya, later became the destination country as a transit country by refugees from Mediterranean countries affected by the Arab Spring, so that in early 2011-2012 the flow of refugees returned increased significantly. The dynamics of the arrival of refugees continues to increase then made the Moroccan government design and implement regulations or regulations governing the handling of migrants and refugees. Law 02-03, which is a regulation on refugees and migrants created by the Moroccan government in 2003, was later replaced by the ratification of the 2011 Constitution which was considered to contain the main principles or principles of Morocco to accept, guarantee rights, and treat refugees and migrants who came to their country better and on a par with Moroccans themselves (Abdeljabbar, 2014).

After the ratification of the 2011 constitution, Morocco then re-endorsed a new regulatory framework in September 2013 called the National Policy on Immigration and Asylum (NPIA) at the instruction of King Mohammed VI. The NPIA further reaffirmed Morocco's attitude 
and response to the arrival of refugees, where one of the points was that Morocco gave UNHCR broader authority to regulate refugee acceptance procedures. The NPIA itself is a clear indicator of Morocco's positive response to refugee acceptance, in addition to expanding cooperation with international organizations related to refugees such as UNHCR, the NPIA also contains other points, namely regularization for migrants and Marko's government plan to integrate refugees with local communities. The positive policies adopted by Morocco have made Morocco considered a country that is quite open to refugee reception which is certainly a magnet for refugees from various regions in Adrika and Middle East. In 2011 UNHCR itself recorded that Morocco accommodated around 1,251 refugees, the majority of whom came from countries affected by the Arab Spring and of these a total of $25 \%$ were children under 18 years (MPC Team, 2013). The number then experienced a significant increase until in 2016, UNHCR recorded the number of persons of concern in Morocco reaching 6,192 with details of 4,043 being refugees and 2,149 asylum seekers. This number is recorded at the end of September 2016, they came from more than 50 countries where $65 \%$ of the total persons of concern came from Syria (UNHCR, 2016). The significant increase in the number of refugees is also an indication that Morocco is getting better at receiving refugees after the Arab Spring.

Furthermore, in the UNHCR report, 427 asylum seekers and refugees have been given registration assistance by UNHCR, and 399 refugees with special needs have access to health and education as well as Moroccans as a form of implementation of the 2011 constitution which further guarantees the rights of refugees in Morocco. Refugees who have been registered and verified by UNHCR means that they have been accepted by the Moroccan government and they have also passed the screening process which means they can continue the process of obtaining a permanent residence permit. A positive response from Morocco is also shown by the fierce repatriation of refugees in the region. Throughout 2016, only 58 refugees left Morocco to participate in the resettlement program, of which 37 were moved to the United States, 19 to Canada, and 2 to France and all were voluntary. This amount was then only added by 2 people who voluntarily repatriated to their home country in Côte d'Ivoire, and this indicated that Morocco had no quota restrictions on accepting refugees and forced repatriation. In addition to repatriation and procedures for accepting refugees who have followed UNHCR's procedures, Morocco also does not involve the military in dealing with refugees in its territory going to Europe via Morocco. The military was also stationed in refugee camps to guard and prevent various criminal acts at the camp. The transfer of refugee responsibilities to civilian institutions is also a form of Morocco's positive response to the acceptance of incoming refugees.

Furthermore, Morocco is also the first transit country to offer permanent residency to migrants or refugees who arrive. Of course, the steps taken by the Moroccan government have received a positive response from the world, especially European countries (Morocco's Legal Migration Policy, 2015). As a transit country, Morocco even provides permanent residence permits for migrants and refugees, which is not necessarily done by destination countries for refugees in Europe and other transit countries in the Mediterranean and Africa. The granting of permanent residence permits is one of the aspects highlighted as Morocco's positive response to refugee reception. On the other hand, Marojo's positive steps in his 
policy towards refugees are in fact still unable to stem the flow of refugees to come to Europe via Spain, which borders directly with Morocco in Ceuta and Melilla, where access to the two regions is fairly easy. The Spanish government recognizes this as an opportunity for refugees from both Africa and the Middle East to come to their country. Therefore, since the 2000s the Spanish government began to tighten security in Ceuta and Melilla (Lanni, 2016). Efforts made by Spain have indeed seen results, since 2010, the number of refugees trying to enter Spain through Morocco has decreased. The number of refugees trying to enter Spain is indeed stagnant, but those who managed to enter continue to decline. Of the total 18,000 migrants who tried to cross Ceuta and Melilla in 2014, 12,000 were foiled from entering Spanish territory and the majority of them were from Senegal and Mali.

Of this number it means that only one third of those who were able to enter either legally or illegally and the majority of those who failed to choose to return to Morocco to apply for asylum or try to find alternative routes through Italy or Greece. But until now, there has been no attempt to prevent refugees from entering or imposing a quota policy for accepting refugees in Morocco. These things then become urgency in this study. The open border policy has indeed made Morocco an attractive country for refugees and this is coupled with regulations relating to acceptance and protection which are quite friendly compared to other transit countries in the same region. Despite pressure from Spain and other European countries regarding control of the flow of refugees, the Moroccan government still chose to accept refugees with regulations that guarantee their rights. From this urgency, an analysis of factors underlying the Moroccan posited response to refugees will be attempted after the implementation of the new constitution in 2011.

\section{Literature Review}

\subsection{Factors Influencing Refugee Policy Choices}

Karen Jacobsen in research entitled Factor influencing the policy responses from host governments to mass refugees influxes trying to explain the factors that affect the response of refugee recipient countries and asylum seekers from various dimensions such as bureaucracy or policy, international cooperation with refugee organizations, to how then the technical is carried out by the state regarding the handling of refugees who enter the country. This concept seeks to explain the response of recipient countries, which are mainly developing countries or less developed countries (LDCs) in Africa, Asia and Central America where developed and industrial countries such as Europe, North America and Australia, Jacobsen then said that the difference in response can be influenced by several factors such as politics, economics, security and military capabilities which then also affect the resilience of LDCs as recipient countries to some problems such as threats brought by refugees. Jacobsen also explained that the response of each different country can be categorized into 3 types of responses to the flow of refugee arrivals, namely do nothing or no response at all, respond positively (accept refugees), and respond negatively (reject refugees). Furthermore, when a country responds by doing nothing this can be caused by the unwillingness of the country's government to respond, the lack of the country's capability to respond, or the possibility that 
the country's government does not see the flow of refugees as an important aspect of its agenda, where this government will be expected to respond when refugee flows come in large numbers so that it exceeds the capacity of the country to accommodate refugees or when the arrival of refugees is considered a threat (Jacobsen, 1996).

Table 1. Factors Influencing Refugee Policy Choices

\begin{tabular}{|c|c|c|c|}
\hline No & Variable & Indicator & Parameter \\
\hline \multirow[b]{2}{*}{1} & \multirow{2}{*}{$\begin{array}{l}\text { Bureaucratic } \\
\text { choices made by the } \\
\text { goverment }\end{array}$} & $\begin{array}{l}\text { Decision to accept } \\
\text { Internatioal assistance }\end{array}$ & $\begin{array}{l}\text { There is foreign aid received by } \\
\text { recipient countries to deal with } \\
\text { refugees } \\
\text { - Positive response: }\end{array}$ \\
\hline & & $\begin{array}{l}\text { Decision to allocate } \\
\text { Responsibility for refugees to } \\
\text { Civilian state agency }\end{array}$ & $\begin{array}{l}\text { Delegation of authority to civil } \\
\text { institutions } \\
\text { - Negative response: } \\
\text { Refugees are handled by the military }\end{array}$ \\
\hline \multirow{2}{*}{2} & \multirow{2}{*}{$\begin{array}{l}\text { International } \\
\text { relations }\end{array}$} & International refugee regimes & $\begin{array}{l}\text { Recipient country status as a } \\
\text { ratification of international } \\
\text { conventions related to refugees }\end{array}$ \\
\hline & & The sending countries & $\begin{array}{l}\text { There are diplomatic relations } \\
\text { between receiving and sending } \\
\text { countries }\end{array}$ \\
\hline \multirow{4}{*}{3} & \multirow{4}{*}{$\begin{array}{l}\text { The absorption } \\
\text { capacity of the local } \\
\text { host comunity }\end{array}$} & Economic capacity & $\begin{array}{l}\text { Infrastructure and unemployment } \\
\text { rate. }\end{array}$ \\
\hline & & & Ethnicity and kindship \\
\hline & & Social receptiveness & Historical experience \\
\hline & & & Beliefs about refugees \\
\hline \multirow{3}{*}{4} & \multirow{3}{*}{$\begin{array}{l}\text { National security } \\
\text { consideration }\end{array}$} & Strategic dimension & $\begin{array}{l}\text { The presence or absence of security } \\
\text { threats brought by refugees }\end{array}$ \\
\hline & & Regime dimension & $\begin{array}{l}\text { Whether or not there is a threat to the } \\
\text { stability of the regime due to refugee } \\
\text { acceptance }\end{array}$ \\
\hline & & Structural dimension & $\begin{array}{l}\text { The presence or absence of scarcity } \\
\text { of resources due to the arrival of } \\
\text { refugees }\end{array}$ \\
\hline
\end{tabular}

The recipient's policy response can be further evaluated through the yardstick which is then adopted from the UN protocols and recommendations related to the issue of refugees, where the evaluation of the recipient's country policy response can be categorized into 2 policy spectrums namely perfectly compliant or positive response and perfect noncompliance or negative response. Positive responses can be seen from recipient country policy responses made in accordance with international recommendations related to refugee issues. While negative responses are seen from the response of state policies that tend to be hostile or alienating refugees. However, the majority of responses from refugee recipient countries can 
be felt in the middle of the spectrum where the policy response to refugees can have the characteristics of positive and negative policy responses. The response of host recipient countries can be varied and very different from one another where this is something that is actually common for countries. The difference which was later underlined by Jacobsen in his writings was that the responses between developing countries or LDCs could be very different from those of developed countries or western countries. This can be influenced by various factors, especially economic, social, political, and military or state security factors. Jacobsen himself then argued that the factors that influence a country's response to influx refugees who come to their country can come from both domestic and foreign or international. In some cases, developing countries will generally consider the decision to receive assistance from abroad related to refugees, which will come mostly from international organizations such as UNHCR, but there are some countries that are also more burdensome to domestic security considerations, so this indicates that the country sees refugees as a form of threat that can disrupt national stability. Jacobsen in his writing then explained four main factors that could accompany the response shown by refugee recipient countries, especially LDCs, including bureaucratic choices made by the government, international relations, the absorption capacity of the local host community, and national security considerations (Table 1).

\subsubsection{Bureaucratic Choices made by the Government}

Bureaucratic choices made by the government in this case refers to the decision of the government of the recipient country to receive foreign aid or not. This is of course very closely related to the decision making process in the bureaucracy of the relevant state government, such as whoever is involved in the policy making process, inputs, outputs, and the policy making flow itself. Bureaucratic decisions made by the government regarding refugees are generally closely related to two things, namely the government's decision to receive assistance from abroad and the decision to hand over refugee management to certain institutions under the social ministry or in a country. Calculation of costs and benefits is certainly an important thing to do by the government before deciding to accept foreign aid or not. In addition, there are also various other considerations such as economic, social, and environmental considerations that must be considered by the government. Even in the policy making process, the government will also listen to input or aspirations from various other actors at the domestic level so that the bureaucratic process in making this decision will proceed.

\subsubsection{International relations}

International relations or international relations in question is a picture of the dynamics of relations between the governments of refugee recipient countries with other actors outside their countries, which are seen more as international actors. Domestic factors are seen as the dominant factor in the policy making process, but basically there are many international factors that also influence the process, especially when the policy subjects made are also international actors. Refugees themselves are basically actors who are seen as a manifestation of the problems that exist in other countries, but then they become a problem in the recipient 
country. Refugee influx or massive movement of refugees into a country will generally affect the dynamics of recipient countries and sending countries, where experts often see it as destructive. This is in the sense that the relations between recipient and sending countries will tend to change in a negative direction. The same thing also affects the dynamics of the relations between recipient and sending countries with international organizations, especially organizations that are indeed focused on providing assistance to refugees. When there is a massive influx of refugees into a country, an international organization that specializes in dealing with refugees will feel the responsibility to provide assistance to refugees and recipient countries. Furthermore, Jacobsen then saw that there were two dominant international factors that most influenced the country's decision making process for refugee arrivals, namely the International refugee regimes and the sending countries.

\subsubsection{International Refugee Regimes}

International refugee regimes has a significant influence on the recipient country, especially in terms of policy making towards the arrival of refugees. The international regime regarding refugees can exert influence on recipient country policies in two ways, namely practical and normative. From a practical point of view, an international regime regarding refugees will be able to exert influence on recipient country policy making by increasing the capability of a country to receive refugees. Of course, this is done by way of physical development. Foreign aid, stimulus for the domestic market, to infrastructure development are things that can be provided by the international regime for refugee recipient countries. This is also seen as a form of appreciation for other countries that are members of the regime towards countries that are willing to accept refugees. These donors or foreign aid will generally be channeled through international organizations under international regimes related to refugees. On the other hand, the international regime regarding refugees also exerts a normative influence on a country's decision to accept refugees. How the country treats refugees who come to their country will be an attraction both for the mass media and international organizations. The status of a country that has ratified a convention or international legal instrument related to refugees will certainly have more responsibility towards the recipient of refugees than a country that has not ratified the same convention. In this case, the international regime has an influence in the form of moral responsibility for refugee recipient countries. Treatment of a country that is bad for refugees will be easily seen by the mass media and international organizations. Various consequences become things that should be considered by a country before they refuse to accept refugees, one of which is bad international publicity in which international organizations can give strong criticism to the country concerned. This will certainly invite the same reactions from various parties so that not only the image of the country deteriorates, but also raises the possibility of other actions from other countries such as the revocation of foreign aid to other forms of international sanctions. Although the influence of the international regime at first glance seems strong enough to influence a country's policy on refugees, but in fact there are several factors that make an international regime actually not so influential. One of them is the issue of sovereignty which is very sensitive for the country. State sovereignty will not be disturbed by anything, including the international regime. The state remains the most authorized party in deciding whether to 
accept incoming refugees or not, regardless of the influence brought by the international regime. However, the international regime and its influence remains an indicator that should be considered in making decisions about accepting refugees, especially for developing countries that need a lot of financial assistance (Krienbrink, 2005).

\subsubsection{The Sending Countries}

The relations between the sending and receiving countries of refugees have always been highlighted by various parties. Refugees themselves are actors who can change the dynamics of a country's international relations. The most observable thing about the dynamics between the sending and receiving countries is the fact that the government of the refugee recipient country will base its decision to grant asylum to the applicant based on their country of origin. The granting of refugee status to asylum seekers from a country gives an indication that the sending country has persecuted its citizens, so this makes the recipient country not want to be considered as the same actor when refusing the arrival of refugees. The relation between the sending country and the refugee recipient country then does not become a dominant factor in determining the treatment of refugees when they enter the recipient country. When the recipient country and the sending country are in a conflictual relationship does not necessarily make the recipient country reject the refugees who come. Recipient countries can deliberately accept them and then be recruited into combatants sent back by sending countries, which clearly violates UN recommendations.

\subsubsection{The absorption capacity of the local host community}

The capacity of local communities for refugees is understood as to what extent the local community of a recipient country is able and willing to accept refugees who enter or refugee influx. Ability or ability is understood as something different from the will or willingnes. Structural capabilities can be seen from tangible or measurable indicators such as the level of the economy, infrastructure, to incoming foreign aid. Whereas willingness or willingness is understood as a more normative thing seen from the perception of local people towards refugees, their attitude or how they treat refugees who enter, to their historical experience with refugees. In general, local absorption capacity is influenced by two indicators, namely economic capacity or economic capacity and social receptiveness.

\subsubsection{Economic Capacity}

Economic factors have been the main determinant in various studies related to policy making, as well as policies related to refugee reception. The economic condition of a country is a vital thing that must be included in the calculation of costs and benefits for each decision, where the economic condition as a large will be directly proportional to the resulting policy output, although this is not always the case. Economic conditions are often a determinant in policy making related to refugee resettlement, until the labor market starts to become a factor that is considered by the governments of refugee recipient countries. Economic capacity itself can be seen from several things, namely land availability, the carrying capacity of the land, employment patterns, and infrastructure. Refugee influx that comes to receiving countries on a massive scale will certainly have its own impact on the environment. Increasing the number 
of human populations in an area will trigger some impacts on ecosystems such as drought or water scarcity, pollution, garbage, to logging for firewood for example.

\subsubsection{Social Receptiveness}

Social Receptiveness is a factor that will affect the willingness of local people towards their attitude or perception in viewing refugees who are strong. The level of acceptance of a community of refugees will also affect whether they will hate or show resistance to refugees due to some economic barriers posed by refugees. However, basically the people who initially accepted refugees will tend to continue to accept refugees in their area even though economic obstacles remain and do not show any negative response. Social receptivity or the level of community acceptance of refugees is important because, the community is the agent who is able to provide assistance to refugees directly. Besides the response shown by the community can be taken into consideration for the government to take policies related to refugees. However, there is no guarantee that the response shown by the public will be directly proportional to the response shown by the government. There are several factors that influence the level of acceptance of local people towards refugees. These factors include ethicity and kinship, historical experience, and beliefs about refugees.

\section{Research Methods}

This type of research used by the writer is an explanative-qualitative research in which the writer will try to explain in detail the causal relationship of a social phenomenon based on the perspective, theory, or concept chosen. Regarding this explanatory research, the author will then try to explain the factors underlying the Moroccan response, especially the policy response to the arrival of refugees from the Middle East and Africa based on variables and indicators that have been defined in the literature review. Data collection techniques used by the authors are secondary data collection techniques in the form of literature studies or literature and document studies. In carrying out this secondary data collection method the writer will use books, journals, work papers, notes, and mass media articles accessed via the internet. Data obtained through literature studies and other sources that have been mentioned by the authors will then be analyzed using the concept of Factors. Influencing Refugee Policy Choices that have been presented by the author in the literature review, where in analyzing the data the writer will look for the relationship or relevance of the data with the research object so that an explanation or exposure will be found in accordance with the concept used.

\section{Acceptance and Morocco Political Commitments to Refugees}

\subsection{Chronology of the Arrival of Refugees in Morocco}

Since before its independence from France in 1956, Morocco has been one of the countries sending large numbers of migrants or diaspora to various regions in Europe. This trend has been going on for a long time since the World War era, where the majority of migrants from Morocco were then sent to Europe as workers. Countries that needed workers from Morocco 
at the time were France and Belgium. This then has implications for the existence of the Moroccan diaspora which is spread evenly in both countries (Lahlou, 2015). From the 1960s to the early 1990s, Morocco only focused on status as a country sending migrant workers. Not only to Europe, Moroccan workers with high skill qualifications are also targeting the North American region as their destination for better jobs. Until now, the North American region has become the default destination for Moroccan expatriates and diaspora. Then for those with low to medium quality qualifications, they prefer to go to Europe and work in several sectors such as industry and construction. At present the number of Moroccan diaspora abroad is 4 million out of the total Moroccan population of 34 million. During the period in which massive emigration took place in Morocco, some changes also occurred. Europe which then had a tightening of border controls in the Mediterranean region made migrants from Morocco have to rack their brains to reach Europe. Changes occur when those who were able to enter as regular migrants are denied access due to various complicated procedures stipulated by the European Union. The migrants must eventually change their status to become irregular migrants and face the threat of punishment or deportation by the authority of the destination country.

It was only in the 1990s that there was a shift in the phenomenon in which Morocco began the arrival of migrants from various countries in the African region. They generally are irregular migrants who have economic motives as their background leaving their country and heading for Europe. Morocco, which is located on the border with Spain, is the main route for the migrant movement (Francoise, 2017). They crossed through the Spanish and Moroccan borders in Melilla and Ceuta, because the region had easier access and a Moroccan border to increase the number of asylum seekers and refugees who entered. The aftermath of the European Union's insistence on Morocco to respond and deal with refugees is the passing of Law 02-03 in November 2003. Under this policy, the Moroccan government clearly criminalizes irregular migration, which will threaten asylum seekers, refugees and migrants others do not have a complete travel document. They are threatened with fines of up to 10,000 dirhams or imprisonment for six months. In addition, those who are detained at the border because the implementation of the regulation will be returned to their country of origin or just abandoned at the border between Morocco and Algeria. After the implementation of Law 02-03, the number of refugees and asylum seekers whose data to Morocco can be seen is decreasing. This is because the implementation of Law 02-03 makes both refugees and asylum seekers threatened not be able to continue their journey to Europe, but instead they are threatened to return to their home countries or displaced in Algeria. They finally sought another route through Libya or other countries in the Mediterranean region. On the other hand, those who are detained on the Spanish border due to the implementation of Law 02-03, must return to Morocco. They have 2 choices, find another route to get to Europe, or settle for asylum in Morocco (Arrach, 2017).

Not a few of them who prefer to settle in Morocco as the second best option. Morocco itself is seen as a country whose economy is quite stable compared to other countries in the African region. The implication of this is that Morocco has begun to receive many asylum requests from those detained in its territory. Those who applied for asylum were generally from Ivory 
Coast, Cameroon, Mali, Democratic Republic of Congo, and Central African Republic. They also generally avoid various conflicts and persecution that are happening in their countries so that UNHCR categorizes them as one of the persons of concern who deserve help. In 2010, the Arab Spring, which began in Tunisia and expanded to Turkey, made thousands or even millions of people displaced people to which they had to flee to other regions or countries. Morocco, although also affected by the Arab Spring but did not cause political turmoil as severe as in Egypt and Tunisia. However, even Morocco was affected by the increasingly massive influx of refugees. Syria, until now, is the largest refugee sending country to Morocco, which number in the thousands every year, based on UNHCR documentation. Since 2010, Syria has become the country that has sent the largest refugees to Morocco. The number of Syrian refugees continues to increase every year and that is also directly proportional to the number of Syrian refugees who choose to settle in Morocco. This is one of the reasons why the Moroccan government then gives greater authority to UNHCR to deal with refugees. The Moroccan government also accepts donations from other countries, especially Switzerland to help manage refugees in Morocco.

Various initiatives then emerged to create a more comprehensive and "friendly" regulatory framework for refugees. In 2013 the Moroccan government came up with regulations that further expanded UNHCR's authority to document refugees and help them to be able to access various facilities such as health and education, to ensure refugees were able to get income or income to survive in Morocco. However, the implementation of policies issued by the government does not always meet expectations. There are still many violations and also the actions of the Moroccan authorities that are not in accordance with their legal basis. Violence against refugees, arrest of women and children, to expulsion or expulsion is still often done by the Moroccan authorities, especially in the border region with Spain and Algeria. This certainly indicates that there needs to be an ongoing evaluation for the Moroccan government to implement the policies that have been made.

\subsection{Composition of State and Ethnic Refugees in Morocco}

The majority of refugees coming to Morocco are from the sub-shara region of Africa. In the early 1990s when the influx of refugees began to arrive massively to Morocco, the majority of them were black Africans who had various motives for leaving their home countries and heading for Europe through Morocco. There are many things that motivate a person to move across national borders, but for those who are then called refugees, there are specific and specific definitions that show they are refugees rather than migrants who move with economic motives. In the first article in the 1951 Convention which had been ratified by Morocco in 1956, a specific definition contained for those considered as refugees. The article states that refugees are those who are forced to leave their country of origin for reasons that clearly and clearly threaten the safety of their lives, these threats can be in the form of conflict, war, persecution, or natural disasters. Refugees who meet these criteria will not always hold refugee status. When other reasons make them refugees have disappeared, they are no longer refugees and can be returned to their home countries (UNHCR, 2017). 
Table 2. Composition of Refugees in Morocco

\begin{tabular}{ll}
\hline Refugees and asylum seekers reghtered by UNHCR in Morocco by nationality \\
\hline Country & Refugees \\
\hline Syria & 2,927 \\
Yemen & 461 \\
Ivory Coast & 281 \\
DR Congo & 150 \\
Iraq & 131 \\
Central African Rep. & 95 \\
Others & 232 \\
Total refugees & 4.277 \\
& Asylumseekers \\
Cameroon & 410 \\
DR Congo & 318 \\
Ivory Coast & 308 \\
Guinea & 215 \\
Mali & 126 \\
Central African Rep. & 109 \\
Others & 424 \\
Total asylumseekers & 1.910 \\
\hline
\end{tabular}

Source. UNHCR, Morocco Factsheet, March 2016.

Syria is currently the largest refugee-sending country for Morocco considering the conditions in that country are indeed very conflictual so that Syrians who come to other countries will be immediately considered refugees without any interview as to be passed by asylum seekers from other countries, which might also be being experiencing political turmoil and persecution many occur there (Table 2, Elshokeiry, 2016).

\subsection{Moroccan Political Commitment to Refugees}

\subsubsection{Development of Moroccan Policy towards Refugees}

Morocco has had a long term as a sending country for migrants even before gaining independence in 1956. In the same year Morocco also decided to ratify the 1951 Convention on refugee status created by the United Nations or the United Nations with the aim of generating joint responsibility regarding handling refugees who are considered as individuals or people who are facing threats or persecution in their home country. Morocco itself is a country that has quite interesting dynamics as sending, transit, and refugee recipient countries. Since the beginning of its independence in 1956 until the 1980s. Morocco is still seen as a sending country of migrants especially to Europe which is more dominated by labor (Arrach, 2017). However, this experienced a shift when in the 1990s, Morocco began accepting asylum seekers and migrants from sub-Saharan regions crossing Morocco to go to countries 
in Europe. The majority of them at that time made the move because of economic motives, although there were some of them who also avoided conflict and persecution in countries of origin such as Ivory Coast and Senegal (Focus Migration, 2009).

Law 02-03, which is Morocco's first regulation made to respond to the arrival of refugees is seen as a regulation that is more concerned with Morocco's domestic security than to regulate refugees and pay attention to their rights. This can be seen from article 42 in the regulation which clearly criminalizes individuals who enter Morocco without official travel documents or passports and visas. This means that, using Law 02-03, Morocco could criminalize refugees and asylum seekers who were considered in the category of Alliens or Foreigners. Law 02-03 is indeed an initial policy framework for Morocco to respond to the arrival of refugees and asylum seekers. The regulation was first formulated in 2002, in response to the European Union's push to tighten safeguards on the Moroccan border, especially in the border region with Spain (Lahlou, 2015). This also underlies that Law 02-03 was passed by parliament only as a response to EU pressure, not to respond to the changing dynamics of refugee arrivals which began to have a significant impact on social and economic life in Morocco. Law 02-03 itself is also seen as an emergency law, in which the ratification of the regulation was carried out because there were many pressures from various parties after the terrorist attack in Casablanca in May 2003. The terrorist attack caused a kind of shockwave in Morocco which implicated the demand to immediately ratify the regulation, where the main point of the regulation is an effort to tighten border guard. Of course, this contradicts the point emphasized by the Moroccan government that Law 02-03 is a regulation aimed at preventing the spread of human trafficking practices and people smuggling into Morocco and other countries bordering Morocco.

Ratification of Law 02-03 is indeed a turning point that is seen as progressive for Morocco, considering that Morocco is the first Arab country to have comprehensive regulations on migrant arrangements, both from the aspect of arrival to what rights are given by the government to those who come to Morocco as seekers, asylum, refugees and ordinary migrants. However, the articles in the regulation show that there is ambiguity or doubt in the Moroccan government in responding to the arrival of refugees as a normal phenomenon, or precisely as a security threat. Article 50 in Law $02-03$ describes various threats of criminal penalties faced by those who enter and leave to Morocco illegally, ranging from fines of $\mathrm{DH}$ $3,000-10,000$ or the threat of imprisonment for up to 6 months. The threat of punishment is intended to reduce the number of trafficking and illegal human smuggling into Moroccan territory. In addition, in article 38 in the same regulation, Morocco also explained that at each border a waiting room has been provided for those who are proven to violate the law until finally they will be driven out of Morocco or returned to their home countries.

In Law 02-03 there is also a classification of aliens protected by the government and guaranteed from the threat of eviction or deportation, including pregnant women and children. This classification is described in article 26, which also includes refugees as one of the objects freed from the threat of deportation. It's just that, in its implementation, many problems were still found. Not only are a number of articles in Law 02-03 considered problematic and give rise to the perception that Morocco is only trying to protect its domestic 
security from the threats brought by refugees, but the implementation of Law 02-03 is also seen as having many weaknesses. The inconsistency in the implementation of Law 02-03 has been the most highlighted by several human rights organizations regarding the arrest of pregnant women to cases of persecution of refugees who were then driven out and abandoned on the Moroccan border with Algeria. Law 02-03 is still the legal basis for several actions carried out by the Moroccan government, especially in combating illegal trafficking and people smuggling. The implementation of the regulation was indeed successful in reducing the space for illegal migrants and refugees to reach Spain through Morocco. This has implications for reducing the number of migrants and refugees coming to Spain through Morocco. Another implementation of the implementation of migrant regulations that further tighten the border guarding of Spain and Morocco makes migrants and refugees have to find other routes to reach mainland Europe. This has affected countries around Morocco such as Algeria and Libya, which have received more massive flows of refugees. To that end, the Moroccan government then decided to take some provocative steps in paying attention to the issue of refugees (Arrach, 2017).

Since 2005, which was considered as a period where Morocco did not get much pressure from European countries after the ratification of Law 02-03, the Moroccan government began to pay attention to countries sending refugees. The Moroccan government began a dialogue and cooperation with the government and ambassadors of migrant and refugee repatriation mechanisms detained on the Moroccan border. In addition, Morocco also began to invite Algeria, which initially ignored the issue of refugees, to work more closely on border controls from the arrival of refugees and other migrants. Furthermore, in 2010 when the Arab Spring emerged and created political turmoil giving a domino effect to the countries in the MENA region, Morocco was not free from this phenomenon. Although Morocco did not experience major protests to demands to change the regime, various pressures emerged to renew the Moroccan constitution to pay more attention to human rights.

King Mohammed VI also committed to meet these demands, where finally in 2011 Morocco officially adopted a new constitution that was considered more concerned with human rights for Moroccans and foreigners in Morocco by guaranteeing their fundamental rights without any discrimination. The 2011 constitution then became an idiotic and operational foundation in determining policy, the establishment of various civil and government institutions, and in the process of implementing Moroccan regulations, including in responding to refugee issues (Lahlou, 2015). Based on article 30 of the 2011 Constitution, Morocco is committed to protecting the rights of Moroccan citizens and also the rights of foreign nationals in Morocco, including providing access to public facilities such as equal health and education. This means, one of the things that must be a concern of the Moroccan government is also paying attention to the rights of refugees.

The more humane 2011 constitution does not necessarily set aside Law $02-03$ as a regulation that forms the basis for regulating migration in Morocco. The 2011 constitution emphasizes that all matters relating to migrants, including refugees, must also be dealt with in ways that pay more attention to individual rights. This means, with the adoption of the 2011 constitution, Morocco will involve several ministries directly to deal with refugees, register 
with refugees accompanied by UNHCR and create a policy framework or plan to help refugees integrate with local communities. Furthermore, after the ratification of the 2011 constitution, Morocco will continue to implement border control as in previous years. However, Morocco's dialogue with the European Union is entering a new phase, especially in the area of border surveillance. In 2013 alone, the European Union and Morocco cooperated in providing easy access for their citizens to travel to Morocco and Europe as a form of appreciation for Morocco's efforts to tighten border guarding and reduce the number of illegal migrants including refugees. It's just that the implementation of this collaboration is still not optimal. Where, there are still many Moroccans who have difficulty getting a Schengen visa. On the other hand, refugees who do not get access through Morocco prefer to turn other routes through Mali or Senegal so that they still have access to Europe. In 2013, Morocco also adopted a policy framework that was considered more comprehensive in dealing with refugee issues in the country known as the National Policy on Immigration and Asylum (NPIA) (Kasroul, 2017).

\subsubsection{Economic Capacity and Overseas Aid After the arrival of refugees.}

Morocco's economy is actually not much different from other countries in the region, they are still categorized as developing countries with a middle income level. Morocco is also a country with an economy that is not too massive as the bay countries, but Morocco has shown relatively stable growth in recent years. Morocco offers workers with relatively lower wages than workers in Europe, so that although Morocco has now shifted its status as a transit country and recipient of refugees and migrants, Morocco is still an exporter of labor for European countries. In 2016, Morocco recorded a labor force of 11.75 million, placing 51 st in the world. And most of these numbers prefer to work abroad than in Morocco for various reasons, such as employment and also relatively lower wages (CIA World Book Fact, 2017).

Morocco as a developing country also relies on the agricultural sector as the backbone of their economy. Despite the massive urbanization, the agricultural sector has never been abandoned by its people. Industrialization has also begun to be intensified by the Moroccan government as an effort to diversify the economy, it's just not been able to absorb a lot of labor. However the industrial sector is considered to have good development, especially in the fields of automotive production, mining and phosphate processing, aeraspace, food processing, energy textiles, construction, to the tourism industry. Morocco itself is a country with a per capita income of $\$ 8,200$ in 2016. The CIA also noted that Morocco has a GDP of $\$ 281.4$ billion where this number has actually been increasing since the last 3 years. However, Morocco's economic growth is seen slowing in 2016 which only stood at $1.2 \%$. In the same year, contributors to Morocco's GDP were dominated by the service sector, especially in the tourism sector at $56.8 \%$, followed by the industrial sector at $29.5 \%$ and the agriculture sector at $136 \%$. Urbanization in Morocco is indeed massive and continues to this day where almost $30 \%$ of the population of Morocco lives in urban areas such as Rabat, Casablanca and Marrakesh. But this cannot be used as a benchmark that Morocco is a developed country. The level of prosperity and illiteration in Morocco is still fairly high, as is the unemployment rate which is also still at $9.4 \%$ in 2016 . Morocco is still a country that has 
many economic problems like other developing countries, and refugees are worried about add to the problem.

The arrival of refugees is often seen as a problem. But for developing countries, the arrival of refugees is seen as an economic opportunity for them to obtain foreign assistance from various donor countries. The assistance can be distributed directly or through UN agencies such as UNHCR. At present, Morocco has 3 main donor countries that channel funds to Morocco through various programs, including in improving services and acceptance of Moroccan refugees. Switzerland, Italy and Monaco are the 3 donor countries, with Switzerland ranked first in 2017 with donations of \$ 493,097. Italy then ranked second with a total of $\$ 85,093$, but this amount was added with donations to respond to Morocco's efforts to suppress the flow of refugees and asylum seekers in the Mediterranean region to $\$ 165,689$. Monaco then came in third with a donation of $\$ 159,236$. In addition to these countries, the European Union also provided some assistance to Morocco to conduct surveillance of refugees. Such as Frontex which helps maintain the borders of Morocco and Spain to an agreement between Morocco and the European Union to facilitate access for citizens of Morocco and the European Union when they want to travel or migrate to their respective regions (Carrera, et al., 2016). As for assistance in infrastructure, UNHCR has been noted to have participated in building camps for refugees in various regions of Morocco. Other non-governmental organizations also open refugee service centers and also skills training centers for refugees, such as Caritas, CARE, Women's Refugge Commission, International Organization on Migration (IOM), and GIZ from Germany. This helped the Moroccan government manage refugees and also helped them to begin the process of integration with local communities and build their respective economies. Because with skilled refugees, they will be able to help turn the wheels of the Moroccan economy, and will also return a good market stimulus if they can start their own business ventures as do some refugees from Syria and other sub-Saharan countries.

\subsubsection{Morocco's Positive Response to Refugee Reception}

Morocco's response to the arrival of refugees varies, but most show a positive response where Morocco does not reject the arrival of refugees and gives permission for international organizations to enter and help solve the refugee problem. Morocco also cooperates with UNHCR in documenting refugees and making plans to integrate migrants and refugees with local communities. In addition, Morocco was also identified as a country that had ratified the 1951 Convention and the 1967 Protocol relating to the status of refugees which became the main instrument and guidelines for countries to treat refugees who came to their countries. Although most showed positive responses, but in the matter of treatment of refugees. Morocco still has some problems. Following is the presentation of the response of Morocco based on the U.N Policy Yardstick: 
Table 3. Morocco's Positive Response to Refugee Reception

Paket Kebijakan I : Legal Bureaucratic Response

Accedes to international
instruments and conventions
Defines asylum seekers as
refugees
Create seprate bureaucartic
authority responsible for
refugees
Procedures for determination
of refugee status

Morocco ratified the 1951 Convention and 1976 Protocol regarding the status of refugees on November 7, 1956 and April 21, 1971, and then made Law 02-03 as a form of accession and was replaced by the 2011 Convention.

Morocco calls people who later migrate, seek asylum or flee to their country as refugees and not aliens.

Responsibility falls under the Ministry of Interior but all implementation of technical procedures is left to UNHCR.

Policy Package II : International Refugees Organization (IROs)

\begin{tabular}{ll}
\hline $\begin{array}{l}\text { Grant IROs permissionto } \\
\text { assist refugees }\end{array}$ & $\begin{array}{l}\text { Morocco allows UNHCR or other NGOs to enter their country and review refugee } \\
\text { conditions there. UNHCR became an IRO with broad enough authority to deal with } \\
\text { refugees. }\end{array}$ \\
$\begin{array}{l}\text { Cooperate with or restrict } \\
\text { IROs }\end{array}$ & $\begin{array}{l}\text { Morocco cooperates with UNHCR in dealing with refugees and follows UNHCR's } \\
\text { recommendations on refugee management mechanisms. }\end{array}$
\end{tabular}

Policy Package III:: Admission and Treatment of Refugees

Admit asylum seekers appearing at border

Screen refugees

Location of refugees

Rights of and restriction on refugees

Refugee Protection

Repartriation

Treatment of longterm refugees
Morocco is willing to accept refugees entering its country, and also willing to be a transit country for other asylum seekers who want to go to Europe.

Morocco has a screening mechanism for asylum seekers or refugees who follow UNHCR procedures.

Morocco places refugees or migrants who transit to their country in camps created by the government and UNHCR.

Refugees living in camps have difficulty mobilizing outside the Moroccan border, this is indicated because of restrictions on sending migrants to Europe mainly through Greece and Spain so that many migrants or refugees detained in Morocco.

But for those in Morocco, they still receive protection and fulfillment of basic rights by Moroccan authorities.

There are still many reports of various acts of violence and intimidation received by refugees in camps, which occur in Morocco, even some reports indicate that violence in refugee camps was carried out by unscrupulous police. In addition, women and children are also often victims of violence in refugee camps.

The Moroccan government only deports or repatriates refugees who do not pass the screening and this is very rarely done, they will generally go to other countries such as Algeria or look for other routes to Europe.

Some refugees are still placed in camps and the process of relocation or integration with local communities is carried out when they have obtained permanent residence permits.

Based on the presentation in the table of country policy packages on refugee reception, Morocco has more dominant positive response characteristics than negative response characteristics. Of all the indicators available, Morocco has almost given an open response to refugees as well as international organizations focused on refugee fields such as UNHCR. Refugee handling procedures have also been adapted to UNHCR's recommendations, so they can also be said to be in accordance with international recommendations. The Moroccan 
government also treats refugees in accordance with its commitments in the constitution, grants permanent residence permits and helps refugees to integrate with local communities, from which the overall response can be considered a country with a positive response.

\section{Factors Affecting Morocco Positive Response to Receiving Refugees}

Morocco's decision to continue accepting refugees has indeed made Morocco gain the attention of countries in the region and also the European Union The positive response shown by Morocco to the arrival of refugees has made Morocco also get various positive responses from other countries and international organizations, especially UNHCR. Since the ratification of the 2011 constitution which is considered to be a constitution based on a commitment to protect human rights, Morocco has begun to open wide borders for refugees and is committed to giving refugee rights the rights of Moroccan citizens.

\subsection{Bureaucratic Choices Made by the Government}

Bureaucratic decisions made by the Moroccan government in this case are important for refugees who come to Morocco. The bureaucratic decisions made by the government regarding refugees will largely determine the fate of the next refugees in Morocco, including whether they have the opportunity to get asylum, or they have to face the threat of being refused entry at the border. Various decisions made by the government will affect the technical implementation of refugee reception and the government's consideration to receive foreign aid or not. Generally, developing countries will be willing to accept foreign aid from developed countries, in the form of financial assistance and infrastructure development for refugees. This assistance will clearly have implications for the country's economy. On the other hand, related to the welfare of refugees in a country is also determined by what decisions are made by the recipient country. This is mainly related to the decision of which institution should be responsible for the arrival of refugees, whether it is a core institution in government such as a ministry or the authority is given to other independent institutions.

\subsubsection{Decision to Accept International Assistance}

When a country decides to accept refugees, of course many things must then be considered by that country, including financial and infrastructure problems. Foreign aid is then considered important to give to recipient countries, especially developing countries like Morocco. UNHCR's annual report on the source and allocation of foreign aid funds received by Morocco continues to increase. Switzerland is the main donor country for Morocco and is followed by Italy and Monaco (UNHCR, 2017). In addition to the three countries, other countries which are members of UNHCR are also contributors to the foreign aid funds received by Morocco every year for technical operations in handling refugees. Acceptance of foreign aid by Morocco is not without reason. Developing countries will generally depend on foreign aid to provide stimulus to the market and domestic development. Getting foreign aid means getting better opportunities to improve the economy and development. Morocco clearly needs foreign assistance. Morocco itself is currently listed as a donor recipient of USAID with total funds provided in 2017 of \$ 82,828 million. 
Although in the UNHCR report Morocco's main donor in dealing with refugee issues is Switzerland, USAID also has an influence on how a policy was formed in Morocco. million allocated to the government and civil society sectors where the United States through USAID also encouraged Morocco to become more democratic and more committed to protecting human rights for both its citizens and foreign nationals in Morocco. In addition to USAID, Morocco is also a beneficiary of economic assistance provided by the European Union (EU). Morocco and the EU have long been seen in mutually beneficial filateral relations, especially in the economic field. Morocco was given fairly easy access to the EU market which certainly gave more stimulus to Morocco's domestic economy. Some of the privileges also accepted by Morocco are the convenience for citizens to get a Schengen visa (USAID, 2017). The decision to accept foreign aid alone was not fully made by King Mohammed VI. The decentralization process carried out by Morocco since 2011 has made actors in the decision making process more pluralistic, such as involving Makhzen, the foreign ministry, and the interior ministry or Ministry of interior (Jaidi, 2018).

\subsubsection{Decision to Allocate Responsibility for Refugees to Civilian State Egency}

The handling of refugees carried out by a country will certainly involve the core institutions in the country. Morocco is one of the countries that places refugee issues as a domestic issue. This means, Morocco does not view refugees as being in the high politics category. This caused Morocco not to place the issue of refugees on its foreign political and security agenda so that the bureaucratic decision regarding the institutions that must be responsible for the refugee issue clearly would not make the Ministry of Foreign Affairs or security as the main body responsible (MPC Team, 2013). Morocco appoints the Ministry of Interior as the party responsible for handling refugees inside Morocco, including how the planned integration and fulfillment of refugee rights is carried out. The appointment of the Ministry of Interior is because in the recent political reforms carried out by Morocco, the ministry was directly responsible for King Mohammed VI. Therefore, in making regulations on migrants and refugees several times and ratification of the 2011 Constitution, all of them were carried out on the instructions of the Moroccan king.

On the other hand, the Ministry of Foreigh Affair and Cooperation is also a ministry that has a stake in implementing Moroccan government policies, especially NPIA which was ratified in September 2013, the Ministry of Foreign Affairs in this case only being the party that connects international parties such as UNHCR and other countries in helping Morocco deal with refugees. The absence of the issue of refugees from the Moroccan foreign policy and security agenda clearly makes the issue of refugees considered an issue that will not bring up high policy. It also means that the issue of refugees does not get enough attention from high-ranking state officials which allows it to be used as a diplomatic tool with other countries or international organizations. Morocco, until now, has not used the issue of refugees as an instrument of diplomacy with other countries including countries sending refugees.

The Ministry of Interior in Morocco has indeed become an institution responsible for the issue of refugees, but they have not issued significant regulations or regulations on the issue. 
UNHCR has instead become an independent institution that has quite extensive authority in managing and documenting refugees. The Moroccan government is even impressed by agreeing to most of the UNHCR recommendations and following all the protocols or procedures for accepting refugees from UNHCR. The handing over of this great responsibility to organizations such as UNHCR indicates that Morocco has not felt fit to include refugee issues in the main political agenda, although the number of refugees who come every year continues to grow, especially from Syria and Iraq. However, Morocco did not show any resistance to accepting refugees. The Moroccan government tends to accept refugees and guarantee their rights under the 2011 constitution and the NPIA that was passed in 2013 .

When a country places the issue of refugees in low politics, there is a possibility that not many parties have an interest in the issue of refugees. They consider that the issue of refugees is not a significant issue or has a major influence on their political angenda. Likewise with Morocco, there are not many political figures who are quite vocal in voicing refugee issues in the political agenda. King Mohammed VI actually became a figure who contributed a lot to several new regulations related to refugees. NPIA is one of the instructions of King Muhammaed VI, as well as the 2011 Constitution which was the result of an amendment to the Moroccan king's instructions. King Mohammed VI, through NPIA also extended the authority to NPIA as a further implementation of the Moroccan Commission to safeguard human rights in accordance with article 30 of the 2011 Constitution. refugees, fulfilling their rights as well as steps to prove that Morocco is a country that is committed to protecting human rights, especially after the massive political tubulency of the Arab Spring in 2010-2011.

\subsection{International Relations}

The intended international relations is the dynamics of the relations between the recipient country and the international regime regarding refugees as well as with sending countries. Both of these entities are important to look at because they are considered the most influential in a country's decision to accept refugees. The international regime can provide a sense of responsibility and moral consequences for the recipient country so that it will bring a positive response to accepting refugees. Another aspect of the relationship between recipient and sending countries also influences the response shown by Morocco. Morocco is indeed a country that is not too aggressive or has significant influence in the region. Morocco is also a country that is rarely heard of having disputes with other countries in both MENA and sub-Saharan Africa which send many refugees to their country. This can be an indication of things that encourage Morocco to show a positive response to the acceptance of refugees.

\subsubsection{International Refugee Regimes}

Morocco is a country from the MENA region which ratified several international conventions related to refugees, both issued by the United Nations and regional organizations in the African region. Morocco itself has ratified the 1951 Convention relating to refugees and also the 1967 protocol regarding refugee status. In addition to the two main international regimes related to refugees, Morocco is also a country that ratifies various conventions and other 
international agreements relating to migrants, migrant workers, and the protection of migrant rights in a region. The international regime has indeed become an important instrument in regulating countries in relation to certain issues. Even though international regimes are not legally binding on the state, these regimes provide moral responsibility for the state to comply and implement legal instruments in the international regime. As is the case with the 1951 Convention and the 1967 Protocol relating to refugee status, where all countries which ratified the two documents have the responsibility and obligation to implement various points contained in both instruments.

When a country has ratified an international legal instrument, the state has an obligation to comply with the legal instrument, but the state remains the highest entity in the international system so that the international legal instruments do not have any binding force on the state. But the international regime still carries a number of normative consequences for the countries that break them. Criticism or even sanctions imposed by other countries against countries that violate international regimes are one of the consequences. Morocco is well aware of this. Being the first African country to ratify the two conventions related to refugees is quite interesting in the eyes of the world, including UNHCR as raised by the protection chief of UNHCR, Volker Turk who has appreciated Morocco's performance in recent years, especially after the implementation of NPIA in 2013. Turk said that Morocco could become a role model for the country in dealing with refugees and Turk also expressed his expectations for Morocco to continue to increase its commitment to protect refugees in the country. Appreciation and expectations expressed by Turk to Morocco can also be interpreted as a responsibility for Morocco to fulfill UNHCR's expectations in terms of protecting refugees. Morocco, led by King Mohammed VI, said it would continue to maintain its commitment. This follows the ratification of the 2011 constitution, NPIA, and Morocco's status as a country that has ratified various international conventions related to refugees.

\subsubsection{The Sending Countries}

Morocco's relations with refugee-sending countries have so far remained quite stable, with no significant conflict or tension between the two countries. The stability of Morocco's relations with refugee-sending countries so far has been caused more by the absence of the issue of refugees from the security agenda and foreign policy in the high politics category. Morocco itself is also known as a country that is relatively calmer compared to other countries in the MENA region, without any significant political turbulence in both the domestic and international spheres. Syria, became the largest refugee-sending country for Morocco at this time after the great crisis that hit the country. However, the arrival of large numbers of refugees had no effect on Morocco's attitude towards Syria. In a bilateral meeting with the Foreign Minister of Saudi Arabia, Moroccan Foreign Minister Saladine Mezouar gave a fairly clear statement about Morocco's attitude towards the conflict in Syria. The meeting held in November 2016 in Rabat was indeed focused on discussing efforts to limit terrorism in Yemen and Syria, where Saudi Arabia is committed to helping Syria out of the prolonged crisis. A different statement came from Mezouar which stated that Morocco would not interfere in the domestic affairs of other countries, including Syria because the issue was not on the foreign policy agenda and security was carried out voluntarily and the countries 
accepted the agreement well without meaningful complaints.

The attitude of Morocco who prefers to maintain good relations with recipient countries is one of the influences on Morocco's policy to accept refugees. The 2011 Convention also guarantees the same thing that Morocco will treat every foreign citizen in its territory as an equal Moroccan citizen. Those who also have refugee cards or residence cards also get legal protection from repatriation or relocation to other countries. This means, Morocco will not question their home country as long as they do not carry significant threats or disturb the stability of Morocco. With this in mind, Morocco will also be able to maintain bilateral relations that are mutually beneficial with sending countries, in addition to the issue of refugees.

\subsection{The Absorption Capacity of the Local Host Community}

Although Morocco implemented a positive policy in responding to the arrival of refugees, there were still some problems encountered in the implementation process in the domestic realm. The community still often shows apathy and resistance to the arrival of refugees. Local media also contributed to the formation of negative public perceptions of refugees. Maroc Hebdo in a publication once gave a label to refugees from sub-Saharan areas with Black Danger associated with members of transnational crime prostitution, human trafficking and drug smuggling organizations.

\subsubsection{Economic Capacity}

Morocco is a developing country in the African region which has a higher GDP than other countries, especially countries in the sub-Saharan region. This makes Morocco a country with a fairly stable economy. With a population of around 34 million. Morocco only has an unemployment rate of $9 \%$. This is also an impact and many Moroccans choose to become a diaspora abroad. Refugees who come to Morocco are not only those without skills, but also those who have certain skills. The arrival of refugees to Morocco is considered to be a contribution to the development of the Moroccan economy. Volker Turk, UNHCR's protection chief, expressed the same thing when visiting Rabat and Marrakesh to review the conditions of refugees in Morocco. Turk said that the refugees who came could actually reduce unemployment in Morocco.

Turk's statement was made following the positive response of the Moroccan government to the arrival of refugees and the many organizations and NGOs concerned and began to empower refugees by teaching them some basic skills. Turk also mentioned that refugees can be a source of investment for the Moroccan economy, where the investment in question is to provide refugee market access to start their own businesses. In addition to the $9 \%$ unemployment condition, Morocco is also in need of workers to work in several agricultural sectors, especially in rural areas. The high level of urbanization makes the rural areas experience barindrain so that the agricultural sector is difficult to develop in rural areas which actually have ample land for agriculture. The service sector in Morocco also experienced the same thing. This is not only caused by urbanization, but also the emigration by Moroccans to Europe and North America. 
With the ever increasing demand for labor accompanied by urbanization and emigration, refugees who come and have official documents can certainly be an alternative to fill the gap. Turk sees optimism about the potential brought by refugees mainly from Syria and Iraq, but does not discredit refugees from sub-Saharan. Turk hopes that the refugees who come can also immediately start participating in moving the Moroccan economy. Morocco itself is not a country that has problems over population. The population recorded at 34 million does not cause excessive levels of population density so Morocco can be said to have no problems with population density after the arrival of refugees. In addition, refugees who have just arrived or failed to enter the Spanish border are not immediately allowed to conduct resettlement in urban areas, they are first accommodated in refugee camps or temporary shelters such as those in melilla to document and arrange residence permits. After they get a resident permit, they can only integrate and relocate to urban and rurral areas.

The various potential refugees might bring as revealed by Turk can be one of the reasons why Morocco opens its borders and is also willing to accept refugees to grant them permanent residence permits, besides Morocco is not a country that has problems with overpopulation or very high unemployment rates, compared to other countries in Africa.

\subsubsection{Social Receptiveness}

The dynamics of Morocco, which was originally a sending country of migrants, later became a transit country and the country of refugee recipients has also more or less influenced the perception of local people towards refugees. Various responses also emerged and were shown by local communities in various ways, both positive and negative responses. Of course the response of the local community cannot be expected to always be directly proportional to the state's response through its policies, bearing in mind that there are other factors that are far more influential than the strategic and economic considerations seen by the state. The local community of a country certainly has their culture, identity, and local perception of something that is influenced by things that are more normative. The historical background of the community, sometimes becomes the dominant factor in shaping this perception. The community's experience of phenomena such as refugees also contributes to the formation of positive or negative perceptions of a community towards the arrival of refugees who try to integrate with them. This also happens in local Moroccan communities who have different views on refugees, especially those who come from the Black Africa region.

\subsection{Ethnicity and Kinship}

Morocco has indeed been a sending country of migrants to Europe for decades, meaning that they don't have much experience with the arrival of refugees before entering the era of the 1990s where there was a massive influx of refugees from the sub-Sabara region. The composition of the Moroccan population itself has an influence on how they respond to black refugees. The majority of the population of Morocco, or more than $90 \%$ of them are ethnic Berber Arabic with the national language is Arabic. The rest are residents from different ethnicities, but the majority of them come from Europe, so it does not cause any social problems considering that the Moroccan people see Europeans as a superior nation. It is different with those who come from sub-Saharan or black Africa. Local people in Morocco 
still have negative perceptions of those who are black. The association of refugees from sub-Saharan with their historical background has long been attached to Moroccan society, the majority of which are from different ethnic groups and are more identical to Arabs. They often associate black refugees with their history as slaves or lower class people. When the assumption has been formed, then various negative stigmas about black refugees will be more easily used as a justification for refusing them to integrate with Moroccan society.

Another perception that has further aggravated racial discrimination in Morocco is the assumption that those who also come from black Africa are members of criminal organizations. Generally, they will be associated with drug cartels, human trafficking, to fraud and money laundering. Although this accusation is sometimes not proven at all, this perception makes it difficult for black refugees to integrate in the midst of Moroccan society. Even some of them often get discrimination and resistance before they have the chance to integrate with the local community. Unlike the case with refugees from sub-Saharan areas. Refugees from Syria seem to get better acceptance than those who are black. Proximity of ethnicity is considered to play a role in the acceptance of local communities of Syrian refugees. Although stigma and sentiment remain attached to the image of refugees, the perception of local Moroccan communities towards Syrian refugees is still fairly positive. And this is also directly proportional to the government's response to how they treat Syrian refugees.

\subsection{Historical experience}

Morocco has a long history of migration phenomena, especially emigration where millions of Moroccans become migrant workers in other countries. Europe and North America are the two main destinations for Moroccans to migrate. They generally look for better economic opportunities and become Diasporas in several countries. The Moroccan Diaspora is well known in various countries in the two regions, they also have a significant influence on the economy and trade activities in the countries they live in. Despite having a long history as a migrant sending country, Morocco is not very familiar with the arrival of refugees before the 1990s. The arrival of migrants, asylum seekers and refugees to Morocco, which began to be massive, did not even receive serious attention from the government in the 1990s. They are only considered as transit migrants who only make Morocco as the main route to Europe. The same assumption then also emerged from people in Morocco who looked at migrants, refugees and asylum seekers who came at that time only for transit, they did not have any bad perception of migrants who came because they did not have the desire to settle. Historical factors, then considered not so significant in shaping the positive response of Morocco in accepting refugees.

Morocco does not have any experience as a country sending refugees they are sending countries migrant workers, and this is more or less influential on the policies taken by the government. The lack of Morocco's historical experience in accepting refugees does not necessarily also make the government later antipathic to the arrival of refugees. It's just that resistance came from Moroccan society, especially those who have a negative view of refugees from sub-Saharan. Although society shows resistance, the history of accepting and 
sending refugees is not a significant factor in the attitude of these communities. Community resistance also does not affect the policy taken by the government to continue accepting refugees from various countries in Africa as well as Syria and Iraq.

\subsection{Beliefs about Refugess}

Although there are differences in treatment and acceptance based on physical and racial issues, in general refugees still get a negative view from the local community. This is closely related to economic opportunities that are increasingly narrow when a country must accept entry into the refugees, this means that there will be more people competing for jobs. Public perception of this matter is very common in developing countries like Morocco. However, it is also important to note that refugee opportunities to access the labor market are not the same as local communities. They still face several obstacles, especially regarding their identity and official documentation. Asylum seekers will certainly not have access to the labor market at all. But this will be different when faced with refugees who already have a registration card or residence permit. They certainly have access to the job market and can get jobs in the formal and informal sectors as well as the local community. This has been guaranteed in the 2011 constitution. Although this is a good thing for refugees, people's perceptions can show different things. Refugees can access the job market meaning competition will be tighter, and of course this makes local people have sentiment towards refugees, such as they are considered to seize the royal court, the cause of falling wage standards, and others.

In addition, another factor contributing to the negative perception of Moroccans about refugees from sub-Saharan areas is their history of being slaves in industrialized countries. The history then gave rise to the perception that people from the sub-Saharan region had education, skills, to the perception that they were inferior to Moroccan society, which is predominantly from the Berber ethnicity. In this case, history actually raises views or perceptions that tend to be racist and form certain stereotypes based on the country of origin and skin color which leads to resistance and ill-treatment of the people against refugees who come to Morocco. The various ill-treatments carried out by the community because of racial perceptions associated with economic motives certainly make the level of people's infiltration of refugees low. In a documentary reported by Al-Jazeera, it shows that Moroccan volunteers who handle refugees admit that they still have negative perceptions of refugees from sub-Saharan areas, and so do the local communities. This perception is formed based on historical background and social phenomena that occur in sub-Saharan countries. Although the level of acceptance of the Moroccan community towards refugees is not very high, especially refugees from sub-Saharan, it does not stop the government from accepting refugees. Government policies with the response of the people themselves are not always directly proportional, there are times when the government must ignore the attitude of the community for the achievement of national interests, in this case Morocco is trying to protect its commitment to safeguard human rights, especially in the case of refugees and asylum seekers and other factors such as the economy.

\subsection{National Security Considerations}

The arrival of refugees to a country cannot be separated from the emergence of potential 
security problems. The arrival of a group of foreigners or aliens into a community in a country to settle is certainly not something that is easily accepted by the people and the country. There are many concerns raised by refugees or asylum seekers who come and try to live in Morocco, where these problems are generally related to human trafficking and also human smuggling which is rife in Morocco and even involves children from various countries in Africa. Human trafficking and smuggling is not new in developing countries, including Morocco. Many things can be behind the actions of trafficking and people smuggling, where one of the main factors is the economy. Morocco itself is a developing country in the North African region. The strategic location of Morocco which borders directly with Spain makes Morocco has a special attraction for traffickers and people smugglers to commit these crimes by sending refugees and illegal migrants to Europe through Spain. To date there are no valid data on human trafficking and smuggling figures in Morocco. However, several international organizations engaged in labor, refugees, and migrants, estimate the number of people who are victims of human trafficking and smuggling in Morocco continues to increase, especially those from sub-Saharan countries such as Senegal and the coast Ivory. They are generally employed in the informal sector such as domestic workers to become victims of sexual exploitation in big Moroccan cities such as Rabat and Casablanca. Generally, women and children are victims of sexual exploitation that are traded both in Morocco itself and later will be sent to Europe via Spain, considering that Morocco borders directly with Spain and has enough access for migrants to easily reach Spain through Ceuta and Melilla.

For refugees and migrants who fail to cross the border with Spain, of course they return to Morocco and stay for some time. Some of them did try to find other routes through Libya or Greece, but most chose instead to settle in Morocco as their second best option after Europe. This certainly makes the number of refugees in Morocco increase and raises problems that must be faced by the government in the form of protecting their rights or sending refugees back to their country for reasons of interest. Human trafficking and smuggling in Morocco is indeed quite massive, where sexual exploitation ranks first. The majority of drug smugglers are migrants from sub-Saharan areas who enter Morocco through illegal channels, but some UNODC findings indicate that the smugglers are now targeting migrants or refugees to smuggle illegal drugs. The security problems brought by refugees are indeed quite diverse in various countries. Morocco is also not immune to these problems, such as smuggling and human trafficking which has implications for the increasing number of transnational crime organizations operating in the Moroccan region, especially drug cartels, which mainly come from countries in sub-Saharan regions such as Ivory Coast, Senegal, Guinea Bissou , and Nigeria. On the other hand refugees who came to Morocco also brought concern about the increasing threat of terrorism, which this had happened before in 2003 when the terrorist act in Casablanca was seen as one of the factors enactment of Law 02-03 which provides regulation and criminalization of illegal migrants who enter Morocco.

Although the issue of terrorism in various refugee-sending countries has also increased over the past decade, the Moroccan government has not been seen making efforts to draw a red thread between the issue of terrorism and the increasing number of refugees coming from 
both the Sub-Saharan and Syria. The Moroccan government is indeed seen making improvements to its regulations for the Moroccan government responding to incoming refugees as a trigger for the increasing threat of terrorism in Morocco. In addition, Morocco does not have any security issues related to the arrival of refugees associated with the stability of the regime as well as the security of the supply of natural resources to meet the needs of the community. The arrival of refugees does create resistance and racial discrimination in society, but the government does not see it as a threat to the stability of the regime. Refugees also did not exert any pressure on the Moroccan government to pay more attention to them, because the initial motive for their arrival in Morocco was only as a transit point before entering the Spanish border at Melilla. The supply of natural resources in Morocco is also fairly safe. The arrival of refugees, as said by Volker Turk, can be an opportunity to fill the labor shortage in the agricultural sector, especially in rural areas. Drought is also not the case because of the arrival of refugees. So it can be concluded that the consideration of Morocco's national security in responding to the arrival of refugees is a factor that is quite influential, where the absence of the perception of the threat of Morocco against refugees is one factor that emerges a positive response.

\section{Conclusion}

After the ratification of the 2011 constitution followed by the ratification of the NPIA, Morocco became the first African country to have a comprehensive policy on procedures and mechanisms for accepting refugees. Despite the pressure that Morocco has received from European countries such as Spain and Greece to further suppress the influx of refugees, Morocco has remained consistent in its commitment to accept refugees and fulfill their rights in accordance with article 30 of the 2011 Constitution. It made Morocco get appreciation and attention from UNHCR. The 2011 constitution and NPIA became the main legal and regulatory basis used by Morocco to accept refugee arrivals. Both make Morocco issued a positive response to the arrival of refugees even exceed other countries in the same region. Morocco is even known to offer permanent residency for refugees who come and have been documented by UNHCR.

Behind the policy which was considered friendly to refugees and humanists, there were several factors underlying the policy, namely bureaucratic choices made by government in which the Moroccan government was willing to accept refugees which had implications for Morocco to be a beneficiary of a large number of foreign aid as well as the handover of handling authority, refugees by UNHCR and the Ministry of Interior. In addition, Morocco is also a country that ratifies conventions and protocols related to refugee status in which it gives Morocco the moral responsibility to participate in protecting refugees as explained in the 1951 convention document related to refugee status. On the other hand, Morocco is also a country that is quite consistent with its attitude not to interfere in the domestic affairs of other countries, including refugee-sending countries and to bring refugees into their foreign policy agenda to continue maintaining good relations with these refugee-sending countries.

The third factor, namely the capacity of local communities for refugees is more influenced by 
economic capacity. Morocco and people's perceptions of refugees. However, the third factor is more dominated by various negative views and stereotypes by the community towards refugees, so that although the government tries to provide protection to refugees, local people still often show racial resistance and discrimination. Fourth, security considerations which also affect the positive attitude of Morocco to accept refugees after the ratification of the 2011 constitution and the NPIA are the government's attention to acts of trafficking and people smuggling that is often carried out on the border between Morocco and Spain. Although the government is willing to accept refugees, the Moroccan government will still be strict in the process of selecting refugees and those who are infected as perpetrators and victims of human smuggling. However, Morocco has issued a statement that refugees and migrants are a source of terrorism threats as was the speculation of many parties after the terrorist act in Casablanca in early 2003.

The four factors that the authors value have the same influence on the ratification of the 2011 constitution and the NPIA. But there are still factors that the authors consider to be more dominant than other factors, such as acceptance of foreign aid and international regimes which are considered to have an effect that will help Morocco in developing its economy and the influence of international regimes will make Morocco more careful in behaving internationally to safeguard good image obtained so far.

\section{Limitation}

The research conducted by the author in this thesis is limited to exploring the factors that influence the positive attitude of Morocco towards the arrival of refugee flows after the ratification of the 2011 constitution and the implementation of NPIA in 2013 as a regulation governing the handling of refugees in Morocco. The author does not look at the side of the success or effectiveness of the policies taken by Morocco in stemming or regulating the flow of refugees who come so that this can be input for further research to measure the success rate of NPIA implementation based on the 2011 constitution.

\section{References}

Allen, T., Morsnik, H. (1994). When refugees go home: African experience. Melton: James Curry Publisher.

Arrach, A. (2017). The Moroccan new immigration plicy and the constituional protection of fundamental human rights of migrants. Hassan University.

Article 1951 and the 1964 Protocol related to refugee status. United Nations.

Brakrajc, M. (2017). Refugees can be a driver of development in Morocco. Retrieved from http://www.unher.org/afr/news/lates/2017/10/59fld50a4/refugees-driver-development-m orocco

Carrera, S. (2016). EU-Morocco cooperation on readmission, borders and protection: A 
model to follow? Retrieved January 3, 2018 from http://www.ceps.cu/system/files/EU-Morocco\%20Cooperation\%20Liberty\%20and\%20S ecurity\%20in\%Europe.pdf

CIA Word Book Fact: Morocco. Retrieved November 27, 2017 from https://cia.gov/library/publications/the-world-factbook/geos/mo.html

Collyer, M. (2012). Responses to irregular migration in Morocco. Institute for Public Policy Research. Retrieved April 15, 2017 from http://www.ippr.org/files/images/media/files/publication/2012/07/irregular-migration-m orocco_July2012_9369.pfd?noredirect=1

Convention and Protocol relating to the status of refugees. United Nations High Commissioner for Refugees. Retrieved December 20, 2017 from http://www.unher.org/3b66c2aa10.pdf

De Bel-Air, F. (2017). Migration profile Morocco. Migration Policy Center. Retrieved December 20, 2017 from http://www.migrationpolicycentre.cu/docs/migration_profiles/Morocco.pdf

Elshokeiry, N. (2016). Egyt post-2012 response to the Syrian Refugee Crisis: A theoretical critique of pratical approaches. The American university in Cairo. Retrieved April 15, 2017 from http://schools.aucegypt.edu/GAPP/PPAD/Documents/PPAD\%20WOrking\%20Paper\%2 0Series.pdf

Focus, M. (2009). Country Profile Morocco. Retrieved November 23, 2017 from http://focus-migration.hwwi.d/uploads/ts_wilpubdb/CP_16_Morocco.pdf

Foreigh AID Explorer by Coutry: Morocco. USAID. Retrieved December 27, 2017 from https://explorere.usaid.gove/cd/MAR

Gillette, L. (2014). Human Trafficking in Morocco: A focus on sub-Saharan migrant women. Independent Study Project (ISP) Collectioon. Paper 1933. Retrieved December 15, 2017 from

http://digitalcollection.sit.edu/cgi/viewcontent.cgi?article=295\&context=isp_collecions

Gosh, B. (2012). The Middle East: After the Arabic Spring Different Word Unfolds. New York: TIME Home Entertainment.

Hass, H. (2016). Moroccan migration trends and development protentials. Retrieved $\begin{array}{llll}\text { November } & 29, & 2017 & \text { from }\end{array}$ https://www.giz.de/fachexpertise/downloads/giz2016-en-moroccan-migration-trends.pdf

Hurwitz, G. A. (2009). The collective responsibility of states to protect refugees. Oxford: Oxford University Press. https://doi.org/10.1093/acprof:oso/9780199278381.001.0001

Jacobsen, K. (1996). Factors influencing the policy responses from host governments to mass refugee influxes. The International Migration Review, 30(3). 
https://doi.org/10.1177/019791839603000301

Jaidi, L. (2018). The Morocco / EU advanced satus: what value does it add to the Europeanghhood policy? The Euro-Mediterranian Partnership. Retrieved from http://www.iemed.org/anuari/2009/aarticles/a149.pdf on January 3, 2018

Kasroul, S. (2017). Morocco establishes itself as a destination for refugees and migrants. UNHCR Official Morroco World News. Retrieved from https://www.moroccoworldnews.com/2017/10/232366/morocco-migration-unher-refuge es/ on December 20, 2017

Knapp, K. (2016). Sub-Saharan refugees finding space and place inabat. SIT study abroad. $\begin{array}{llll}\text { Retrieved November } & 25, & 2017 & \text { from }\end{array}$ http://digitalcollections.sit.ed/egi/viewcontent.cgi?articlle=3402\&context=isp_collection

Krienbrin, A. (2005). Country of emigration and new contry of immigration? Challenges for Moroccan migration policy between Africa and Europe. Wiener Zeitschrift fur criticalche Afrikastudien. Retrieved November 25, 2017 from http://stichproben.univie.ac.at/fileadmin/user_upload/p_stichproben/Artikel/Nummer08/ 11_Kreienbrink.pdf

Lahlou, M. (2015). Morocco's experience of migrations as a sending, transit and receiving country. Istituto Affari Internazionali. Retrieved April 17, 2017 from http://www.iai.it/sites/default/file/iaiwp1530.pdf

Lanni. Alesaandro. (2016). Apolitical laboratory how Spain closed the barders to refugees. Open Migration. Retrieved 18 November 2018 from https://openmigration.org/en/analyses/a-political-laboratory-how-spain-closed-the-borde rs-to-refugees/

Morocco Demographics Profile. (2017). Retrieved 7 January 2018 from https://www.indexmundi.com/morocco/demographics_profile.html

Morocco's Legal Migration Policy. (2015). Al-Jazeera Online News Portal. Retrieved from http://www.aljazeera.com/programmes/insidestory/2015/09/morocco-legalmigration-pol icy-150906

\section{Copyright Disclaimer}

Copyright for this article is retained by the author(s), with first publication rights granted to the journal.

This is an open-access article distributed under the terms and conditions of the Creative Commons Attribution license (http://creativecommons.org/licenses/by/3.0/). 